DOI: 10.15393/j9.art.2019.6842

УДК 821.161.1.09"1917/1992"

А. Г. Гачева

Институт мировой титературы им. А. М. Горького, Российская академия наук (Москва, Российская Федерация) a-gacheva@yandex.ru

\title{
Софийная тема в художественно-фидософском наследии Валериана Муравьева: от мистерии «София и Китоврас» к роману «Остров Буян»
}

Аннотация. Тема софийности, характерная для русской религиознофилософской мысли конца XIX - первой трети XX в., впервые рассматривается в статье применительно к художественному и философскому творчеству Валериана Николаевича Муравьева (1885-1930). В философской мистерии «София и Китоврас» (1921-1925) Муравьев соединяет две линии разработки софиологической темы - богословскую и художественную. София предстает на страницах мистерии как идеальный образ мира и человека, и одновременно ее образ связан с темой смысла любви, с этикой преображенного Эроса. Показано, как ключевая сцена мистерии молитва к Софии всей природы и всего человечества и следующее за молитвой общее дело преображения мира - переходит в другие художественные замыслы Муравьева, отражается в набросках сказки «Полоненное царство» (1925) и в неопубликованном романе «Остров Буян» (1926-1928). В свете софийного сюжета рассмотрена драма философа «Советник смерти» (1927-1928). Показаны автобиографические истоки софийной темы у Муравьева.

Ключевые слова: художественное и философское творчество В. Н. Муравьева, софиология, мистерия «София и Китоврас», роман «Остров Буян», пьеса «Советник смерти», преображение мира и человека, мотивы, образы, автобиографизм

Об авторе: Гачева Анастасия Георгиевна - доктор филологических наук, ведущий научный сотрудник, Институт мировой литературы им. А. М. Горького, Российская академия наук (ул. Поварская, 25a, г. Москва, Российская Федерация, 121069)

Дата поступления: 01.06.2019

Дата публикации: 18.10.2019

Для цитирования: Гачева А. Г. Софийная тема в художественно-философском наследии Валериана Муравьева: от мистерии «София и Китоврас» к роману «Остров Буян» // Проблемы исторической поэтики. 2019. — T. 17. — № 4. - C. 242-272. DOI: 10.15393/j9.art.2019.6842 
«Л любил женщину, именуемую Софиею»'. Этими словами философ, публицист, дипломат Валериан Николаевич Муравьев начал один из набросков к своему главному сочинению философской мистерии «София и Китоврас»². Он работал над мистерией в первое пореволюционное десятилетие (с 1918 по 1925 г.), когда внешняя, политическая история, совершившая марш-бросок из «царства необходимости в царство свободы», развивалась в активном противостоянии самодержавному прошлому, однако другая - внутренняя - история, находилась отнюдь не в одномерных отношениях с дореволюционной эпохой: темы и образы Серебряного века звучали в ней, то окрашиваясь ностальгически, то обретая новые обертоны в соприкосновении с современностью.

Если говорить о самом Муравьеве, то, бывший участник Санкт-Петербургского Религиозно-философского общества, еще до революции напечатавший несколько статей в «Русской мысли» и «Московском еженедельнике», а в 1917-1918 гг. регулярно публиковавшийся в журналах «Русская свобода» и «Заря России», он воспринял от Серебряного века целый ряд тем и сюжетов: оправдание истории, искусство как творчество жизни, имяславие, которое вместе с друзьями-философами А. К. Горским и Н. А. Сетницким трактовал как переход к имядействию [Hagemeister], [Гачева, 2015]... Но, пожалуй, центральной, обнимавшей все прочие темы, стала для него тема Софии. Образ Премудрости, что была у Бога художницею, помогая Ему в творении мира, связывался в представлении Муравьева и с идеей истории как работы спасения, преодолевающей внешний и внутренний хаос, и с темой вселенского искусства, преображающего мир в красоте, и с видением универсума как иерархии, лествицы имен, возводящей к Божественному Имени.

Диапазон софийной темы в русской культуре был задан В. С. Соловьевым (см.: [Козырев], [Сапронов: 68-103]). Им же были прочерчены две линии ее осмысления, которые можно условно назвать богословской и художественной. В первой трети XX в. каждая из них получила свое дальнейшее углубление и развитие. Первая линия брала свое начало в соловьевской концепции всеединства и Церкви как орудии ее 
восстановления в падшем и смертном мире, атомарном, разрозненном, существующем по закону «двойной непроницаемости» ${ }^{3}$ вещей и существ. Эта линия вела к П. А. Флоренскому и С. Н. Булгакову и выводила к новой постановке вопросов христианской космологии и антропологии. В книге «Философия хозяйства» С. Н. Булгаков определял Софию как образ благобытия, целостный, совершенный образ мира и человека, который пребывает в Боге от века, являя высшую красоту, славу и нетление. И одновременно Премудрость Божия - посредница между Богом и миром, она не оставляет бытие и после того, как в грехопадении входят в него смерть и рознь, изливает в природу божественный свет, живой нитью связывает его с Богом ${ }^{4}$. Водительница Твари, София направляет человеческий род и природу к восстановлению утраченного всеединства. Тот же аспект софийной темы подчеркивал П. А. Флоренский, для которого «София - эта истинная Тварь или тварь во Истине, - является предварительно как намек на преображенный, одухотворенный мир, как незримое для других явление горнего в дольнем» ${ }^{5}$. Трактуя в книге «Столп и утверждение Истины» иконографию Софии, Флоренский видел в окружающих Премудрость Божию небесных сферах знак ее вселенской, «космической власти», ее «космократии» ${ }^{6}$.

Флоренскому была близка позиция Соловьева, связавшего тайну Софии с тайной Троицы, подчеркивавшего, что София есть «абсолютное единство» ${ }^{7}$ Божественных лиц в их неслиянности-нераздельности. И одновременно Флоренский акцентировал присутствующее в Церковном сознании и запечатленное иконописным искусством видение Софии как Церкви. Описывая так называемую ярославскую версию образа Софии, основанную на знаменитой фразе «Премудрость созда себе дом» ${ }^{8}$, он подчеркивал, что это изображение является образом «Церкви в ее целом». А обращаясь к иконе Софии, представленной в Софийском соборе г. Киева, где София изображена в виде крылатой Богоматери, стоящей на серповидной луне в окружении ангелов и архангелов, праотцов и пророков, видел в ней «соединение Софии, Богоматери и апокалипсической женьl», облеченной в Солнце, образ которой представлен в «Откровении Иоанна Богослова» (Откр. 12:1-6). 
Вторая линия разработки софийной темы опиралась на образы соловьевской поэмы «Три свидания» (1898). «Сиянье Божества», прозреваемое поэтом-мыслителем под «грубой корою» материи, вещественного, тварного мира, сфокусировалось здесь в лучистом видении «Подруги вечной». Душа Мира предстала в прекрасном женском облике, утверждая высший, богочеловеческий «смысл любви» - как дела обожения. «Три свидания» соединили культ Богоматери как Непорочной Девы, образ Ее как покрова и упования твари, как энтелехии материи, чающей преображения в Богоматерию, с гётевским «Das Ewig Weibliche», и это единство получило разнообразные проекции в эстетике и художественной практике русского символизма, у А. Блока, А. Белого, В. Иванова.

В мистерии «София и Китоврас» В. Н. Муравьев соединяет обе софийные линии философии и литературы Серебряного века, внося в их звучание свои характерные обертоны. Философ синтетического склада, он возводит храм своей творческой мысли на фундаменте, содержащем скрепы самых разных традиций: от раннего христианства до гностицизма (см.: [Гачева, 2014]), от европейской философии до восточных Упанишад, от древнерусской былинной традиции до современного богоискательства, - но при этом не допускает эклектической пестроты, расплывчатости образа, лишенного ценностной фокусировки. Беря из этих традиций присущие им варианты понимания «женского», он переплавляет их в христианском горниле и этот творческий сплав обогащает теми идеями и пониманиями, которые дало ему соприкосновение с наследием Н. Ф. Федорова, В. С. Соловьева, Н. А. Бердяева, для которых христианство - религия действия, реального преображения мира.

Так рождается образ главной героини мистерии. София внешне - «светская женщина, одна из самых красивых, обаятельных и знатных петербургских женщин» ${ }^{10}$, внутренне искательница правды, жаждущая «не только знания, но и жизни» ${ }^{11}$ Уже несколько лет является она участницей религиозно-философского общества, члены которого одушевлены идеей «найти и построить идеальное царство человеческих отношений» ${ }^{12}$, но никак не могут достигнуть согласия, ибо 
каждый из спорящих видит это царство по-своему. Она же взыскует абсолютного, целостного идеала, и на этом фоне резче и выпуклее видит изъяны дробных, частичных идей, фанатично отстаиваемых ее собратьями.

В одну из весенних петербургских ночей в садике перед Исаакиевским собором, куда София, уставшая от светской пустой болтовни, скрылась с блестящего бала, она неожиданно встречается со странным человеком в крылатке и котелке. Завязывается разговор, в котором собеседник Софии обнаруживает поразительное знание ее духовного и душевного склада, особенностей поведения, сокровенных мыслей и чувств. София недоумевает: уж не из тайного ли ведомства сей незнакомец? Однако тот отметает ее подозрения. На деле он никто иной, как загадочный Китоврас, в библейские времена помогавший царю Соломону в строительстве Иерусалимского храма, как о том повествует древнерусская «Повесть о Соломоне и Китоврасе». Самой же Софии герой открывает, что она является земным воплощением Премудрости Божией, и ее миссия - быть водительницей человечества к совершенному строю жизни.

Впрочем, до осуществления этой миссии еще далеко. София - сама пока только искательница, которой предстоит прийти «в разум истины», к пониманию сущности совершенства. И потому Китоврас становится ее Вергилием: в последующих сценах-видениях он ведет Софию по царствам, в которых воплощены философские и религиозные представления человечества об идеальном социальном устройстве. Царство Адаряна, пошедшего по пути индивидуализма, опирающегося на силу и власть; царство Навуходоносора, обращенного Богом в зверя и исповедующего слияние человека с природой, погашение личности в роевой, бессознательной жизни; царство Мельхиседека, стоящее на христианстве в историческом его изводе - с идеалом аскетизма, отвержением несовершенного мира, идеализацией потусторонности; «царство Блудницы», рисующее образ секулярной цивилизации, сознательно отрекшейся от Христова завета; «царство подземных людей», воплощающее идеал социализма - обрубленный, оскопленный образ социального действия, полноту которого заключает 
в себе, по Муравьеву, лишь активное, творческое христианство, стоящее на принципе богочеловечности.

Искание совершенной модели жизни, истинного царства правды - центральная тема «Софии и Китовраса». Это искание опирается и на христианский идеал "нового неба и новой земли», и на народные легенды о праведных землях: Опоньском царстве, земле Игната, «Царстве Пресвитера Иоанна», где «небо и земля соткнулись» ${ }^{13}$. Самый ареал странствий Софии был максимально широк, обнимая собой все времена и эпохи. В облике странницы София оказывалась в Вавилоне и в империи Александра Македонского, беседовала с царями и мудрецами, с военачальниками и философами, стремясь услышать от них чаемую «последнюю правду». Муравьев планировал ввести в мистерию исторических и мифологических персонажей. Там должны были действовать царь Соломон, Александр Македонский, жрица Диотима, философы Сократ, Сенека, Марк Аврелий ${ }^{14}$. И каждая эта встреча являла новый облик Софии, демонстрируя всеобщность проявления софийного образа в каждой женщине в каждую эпоху истории. София-амазонка встречалась с Навуходоносором, София-пленница, прекрасная персиянка, супруга воеводы Гастаспа, спорила с Александром Македонским. Примечательно, что смена облика не влияла на внутреннее устроение той, что призвана была воплотить в себе вековечное алкание правды, взыскание совершенства. Не случайно в диалоге с Александром Македонским, величайшим из полководцев, стремившимся поразить Софию мощью и великолепием земной власти, она, духовная страница, твердо отвечала, что ни над душой, ни над волей ее он, повелитель мира, не властен ${ }^{15}$.

Обращаясь к разным эпохам и разным культурным традициям, Муравьев стремился показать универсальность исканий идеального состояния мира. В то же самое время он демонстрировал и глубокую национальность этих исканий, их укорененность в почве древнерусской культуры. Так появились в мистерии странники, калики перехожие: в их образе шли по степным пространствам София и Китоврас. Фольклорные истоки отчетливо проявились и в образах героев-искателей, 
готовых завоевать для Софии вожделенное царство. В одном из планов мистерии Китоврас, выступающий в роли Соломона, «зовет всех искателей Софии, объявляет им, что София отдаст свою руку тому, кто завоюет ей достойное царство» ${ }^{16}$, и на его зов откликаются три богатыря: Святогор, Полкан и Егорий. Двое первых строят ложные царства (первое основано на праве одинокой личности, второе - на безбожном коллективизме и подавлении индивидуального «я»). И лишь третий искатель, Егорий, как и требует фольклорный сюжет, слагает к ногам Софии подлинное, совершенное царство, основанное на христианской соборности, действии и любви.

На образе Егория и его связи с Софией следует остановиться подробнее. Линию «Егорий - София» Муравьев заимствует из знаменитого духовного стиха о Егории Храбром и трансформирует в соответствии с собственным замыслом. Еще до рождения мистерии, в статье «Русский революционный мессианизм», открывшей серию статей философа 1917 г. в журнале «Русская свобода», он назвал Егория тем героем, в котором во всей полноте выразился облик «русского народа», проявились его заветные чаяния. По сюжету духовного стиха Егорий предстает как «сын Софии-Премудрости», и эту сыновне-материнскую связь Муравьев трактует как манифестацию "родства России со всем миром, со всем творением» ${ }^{17}$. В интерпретации Муравьева, Егорий, сын Софии, души мира, водительницы твари к совершенству, подобно своей матери, исполнен душевного попечения о бытии, той любви ко «всякому созданию Божию» ${ }^{18}$, которой говорит в романе «Братья Карамазовы» старец Зосима. Егорий, по велению которого «разрастаются леса, бегут реки, становятся горы, живут звери, рыбы, птицы» ${ }^{19}$, воплощает в своих «творческих подвигах» ту идею благой «регуляции» мира, которая была центральной в философии Н. Ф. Федорова, перейдя затем в христианскую философию хозяйства С. Н. Булгакова. Народное сознание, в представлении Муравьева, выражает здесь образным, «неученым» образом идею регуляции природы, ософиения, космизации мира.

Дав в своей публицистике религиозно-философское прочтение темы софийности - в контексте идеи обожения твари, - 
Муравьев дополняет его в мистерии интуицией просветляющего, преображенного эроса. В древнерусском стихе Егорий является сыном Софии, а в героине духовного стиха подчеркнуто идеальное материнство - тем самым и тема спасения Софии, метонимически воплощающей собою весь мир, проецируется на новозаветный сюжет: Христос спасает все бытие, в том числе и Богоматерь. У Муравьева, наследника Серебряного века, где тема преображенного Эроса питалась идеями соловьевского «Смысла любви» (1892-1894) и образом «Подруги Вечной» в его поэме «Три свидания», образ Софии-Матери замещается образом Софии-Невесты. Егорий здесь не сын, но суженый Софии, подобный царевичу Елисею из пушкинской «Сказки о мертвой царевне и семи богатырях», который избавляет возлюбленную царевну из-под власти смертного сна.

По мере кристаллизации замысла фольклорные и сказочные мотивы, характерные для начальных планов мистерии, сменяются мотивами, утвердившимися в эпоху книжной культуры, и за поклонением Софии героев-искателей отчетливо встает средневековый культ Прекрасной Дамы, возрожденный романтизмом, а затем символистской эпохой в лице Блока и Белого. Глава «София» одного из прозаических вариантов мистерии начинается исповедью героя, признающегося, подобно лирическому герою соловьевской поэмы «Три свидания», в вечных чувствах к подруге вечной:

«Я любил женщину, именуемую Софиею. - Ею душа моя была изранена с ранних лет и мир от раны той для меня потускнел и жизнь наполнилась алканием света и обретением страдания.

Она была земной и небесной и потому тоска ее перемежалась с нездешней радостью. Но я не мог вынести ее тоску. Все отдам тебе, сказал я ей, всю душу свою, весь ум, все сердце, всю силу, бурлящую в жилах. Но она отвечала: на что мне душа твоя, ум твой, сердце твое, сила твоя. Мне нужно другое, настоящее... Мне нужно царство.

И я задумывался мучительно и страстно над этим другим, над этим настоящим, над этим царством. Весь мир завоюю тебе, говорил я ей, все царства настоящие, прошлые и будущие. Вдохновленный тобой я чувствую в себе мощь непреоборимую, 
смелость безумную, волю железную. Но она отвечала: не эти царства нужны мне. Мне нужно единое светлое царство. Его высота выше всех высот, его глубина глубже всех глубин, его широта шире всех широт. В нем все царства как в семени; оно земное и небесное; в нем радость единственная, радость преображения, радость жизни неисчепаемой и вечной.

И я сказал: Клянусь, что я добуду это царство, и грусть в твоих глазах сменится предвечным светом херувимов! ${ }^{20}$.

Характерно, что в отличие от «Подруги вечной» соловьевской поэмы «Три свидания» образ, рисуемый Муравьевым, более определенен в своей человечности, но при этом не теряет идеальности. Платоновский дуализм, резко разграничивающий сакральное и профанное, небесное и земное, Афродиту Уранию и Афродиту Пандемос, преодолевается евангельским пафосом воплощения спиритуального и обожения земного. Муравьев воспринял от русской религиозно-философской мысли, пути которой были неразрывны с путями литературы, образ христианства как преображающей, жизнетворческой веры, идею христианского реализма, преодолевающего романтическое двоемирие. Его София - и в подготовительных материалах к мистерии, и на этапе воплощения замысла - отнюдь не бледная, возвышенно-бесплотная, спиритуальная тень. Она исполнена жизни, полна женского и человеческого обаяния, в ней - подвижный, пытливый ум, горячее, неравнодушное сердце. И одновременно - София страстно стремится к свету истины, отвергая всякие компромиссные решения, сознательно оскопляющие, ограничивающие идеал.

В. Н. Захаров, обосновывая «христианский реализм»как метод русской литературы, подчеркивал: «Как эстетический принцип христианский реализм появился задолго до открытия художественного реализма в искусстве. Он проявляется в новозаветной концепции мира, человека, в двойной (человеческой и Божественной) природе Мессии» [Захаров, 2001: 10]. Связь христианского реализма с темой Боговоплощения, заявленная в данном высказывании ученого, была внятна Мyравьеву, как была она очевидна для Достоевского, видевшего в Боговоплощении, в том, что «слово плоть бысть» (Ин. 1:14), 
не просто основание веры, но и неложное свидетельство полноты миропреображения, просветления материальности. Достоевский, в творчестве которого христианский реализм, "реализм в высшем смысле», обрел полноту выражения [Степанян], [Касаткина], на знаменитых «фантастических страницах» романа «Бесы» [Захаров, 2008] заявлял: «Да Христос и приходил за тем, чтоб человечество узнало, что его земная природа, дух человеческий может явиться действительно в таком небесном блеске, в самом деле и во плоти, а не то что в одной только мечте и в идеале, что это и естественно и возможно» ${ }^{21}$.

Идеи и образы Достоевского прочно вошли в философский и художественный мир Муравьева (см.: [Гачева, 2012], [Гачева, 2013]). Единство Божественного и человеческого, которое утверждалось в мысли и творчестве автора «Братьев Карамазовых», его "реализм в высшем смысле», уничтожающий всяческое, даже самое внешне благочестивое, разделение планов бытия, - вот мировоззренческая и творческая опора, на которой выстраивает Муравьев здание своей мистерии. Со всей определенностью этот реализм Достоевского - христианский реализм, видящий мир в перспективе преображения, проявляется у философа в развитии именно софийной темы, в коротком, но емком определении: «Она была земной и небесной».

Соединяя в себе земное и небесное естество, София одновременно воплощает единство любви и мудрости, сердечности и ума. Финальной сценой мистерии, как она изначально задумывалась Муравьевым, была встреча героини с Пресвитером Иоанном, царем-священником, правителем праведной страны, как о том повествует «Сказание об Индийском царстве», знаменитый памятник средневековой греческой литературы XII в., воплотивший в себе извечные чаяния о Царстве Божием на земле и широко известный как в средневековой Европе, так и в Древней Руси. В черновых версиях мистерии «прообразом» этой сцены была встреча Соломона с царицей Савской. Этот эпизод, рассказанный в III книге Царств (3 Цар. 10:1-13), на славянской почве стал основой «Сказания о премудрости царя Соломана и о южской царице и о философех». Согласно 
сказанию, царица Савская, услышав о мудрости Соломона, решила «испытать его загадками», а затем и сама пришла к царю, проверяя его мудрость вопросами [Памятники старинной русской литературы: 61-63]. У Муравьева, встречая Софию в своем Царстве, Пресвитер Иоанн прямо сравнивает ее с Царицей Савской и называет «Мудрейшей из жен» ${ }^{22}$. Правитель «земли Беловодской», за которой отчетливо встает образ Царства Божия на земле из двадцатой главы «Откровения Иоанна Богослова», сообщает героине, что, подобно Соломону, он готов ответить на ее вопрошания. И здесь библейский и древнерусский рассказ меняют свое течение. София у Муравьева не просто испытывает на прочность мудрость Иоанна - она стремится понять, соединена ли эта мудрость с высшей правдой и высшей благостью, потому что именно это соединение является для нее (как и для автора мистерии) залогом цельности, прочности и совершенства того Царства, которым правит ее собеседник.

Мудрость самой Софии не имеет ничего общего с голым «рацио», - это ум, сведенный в сердце, обрученный с любовью, жаждущий дела. Со всей очевидностью это проявляется в сцене, предшествующей встрече героини с Пресвитером Иоанном. Пройдя все царства земные и ни в одном из них не увидев «единственного, истинного, последнего царства» ${ }^{23}$, героиня оказывается в безводной пустыне. По черновым версиям мистерии, вся окрестность усеяна обломками рухнувших царств (такова, с точки зрения Муравьева, судьба всякого дробного, частичного идеала, не дерзающего на полноту, не способного расшириться до совершенства $\left.{ }^{24}\right)$; в окончательной версии, переосмысляющей символику «Откровения...», София видит «развалины Вавилона-града, поросшие травою волчецом» ${ }^{25}$. Как София Ахамот в гностическом мифе, аллюзии к которому со всей очевидностью присутствуют в этой сцене мистерии, героиня, затерянная в пустыне, доходит до предельной точки отчаяния. Но в этот момент к ней начинает взывать вся природа: травы и облака, гады и змеи, насекомые, птицы, звери они молят Софию спасти их от смертной участи, ввести в чаемое царство правды. Слыша голос живой твари, что надеется превозмочь отпущенный ей удел, взыскует совершенства 
и вечности, освобождения «от тяжести и цепей» ${ }^{26}$, София обретает понимание того, к чему призвана она в этом мире, декларируя в качестве своего credo единство знания, чувства и действия: «Я чувствую, что я не могу только знать. Мне надо любить u делать! <...> Я поняла страдания камней, растений, животных, всей природы, ее внутреннее восстание против слепоты навязанных ей законов, и я знаю: мой долг помочь ей» ${ }^{27}$.

Отвергая знание ради знания, София у Муравьева отвергает и путь одиночного спасения, который предлагает ей Китоврас, появляющийся в пустыне в ответ на мольбу героини. Крылатая София может перелететь через пропасть, отделяющую исхоженное ею пространство от чаемой обители Пресвитера Иоанна, видение которой открывается на горизонте. Но она отказывается бросить страждущую тварь земли, ответственность за которую взвалила на свои плечи. Ответственность не только за бессловесных существ, обретающих в мистерии разум и голос, но и за весь род людской: его олицетворяют в мистерии народные правдолюбцы, которые после долгих странствий приходят в пустыню ждать и искать Софию, веря, что она приведет их в чаемый Град. А вслед за ними подтягиваются и бывшие строители Бенсалема - так называли себя члены религиозно-философского общества, к которому когда-то принадлежала София. Раньше каждый из них отстаивал и пытался воплотить в жизнь свою правду, но теперь, после краха защищаемых ими идеалов, они готовы следовать за Софией и содействовать ей, предлагая построить дорогу «в обетованный Город» ${ }^{28}$. В финале сцены в пустыне София из страждущей, сомневающейся, ослабевшей превращается в заступницу творения, водительницу его к чаемому Царствию Божию. Она, Душа мира, призывает все существа - от растений, камней, животных до человека - принять участие в «великом труде», засыпать бездну между двумя мирами. А в завершающей сцене мистерии, носящей название «Новый Бенсалем», в котором угадывается образ «Нового Иерусалима», пространством общего дела, великого труда, ведущего к «окончательному преобразованию мира, к победе над тлением, временем и смертью» ${ }^{29}$, становится уже не только земля, но и Вселенная, а деятелями - все существа и все элементы мира, 
«люди, животные, камни, растения, звезды и планеты, атомы и электроны» ${ }^{30}$.

Акцент на теме мудрости, знания, звучащей в мистерии, заставляет закономерно обращаться к гностическим мотивам «Софии и Китовраса». Об этом мне уже приходилось писать в специальной статье (см.: [Гачева, 2015]). Здесь же следует отметить главное: гностицизм Муравьева - гностицизм, преломленный сквозь христианскую призму: в нем нет характерного для гностического образа мира дуализма спиритуального и материального, духа и плоти, он отталкивается не от материи как таковой, а от нынешнего состояния материи, пребывающей во власти смерти и тления. Знание у мыслителя тесно связано с делом, с искупительным подвигом, дух проницает материю и стремится просветлить ее изнутри. По-своему трактуется Муравьевым даже тот поворот сюжета мистерии, когда на зов Софии в пустыне появляется Китоврас: действие здесь прямо отсылает к гностическому мифу, где Иисус или посланный им Параклет спасают Софию Ахамот, возводя ее из материального мира в Плерому. Но если Параклет гностиков возвращает в Плерому только Софию, вслед за которой право на вход получают лишь избранные (пневматики), поставившие дух и свет выше страсти и тьмы, а низший, материальный мир сгорает, как зло, то у Муравьева в Царство Пресвитера Иоанна входит все бытие.

Мистерия «София и Китоврас» - не только художественно-философский, но и автобиографический текст. Прототипы ее героев Муравьев находил в своем ближнем и дальнем окружении. Подобно своим старшим собратьям, прозревавшим лик Небесной Невесты в реальных, земных избранницах, он собирал образ героини-искательницы из образов реальных лиц, из кирпичиков женских судеб. Кто были эти женщины, отразившиеся в его Софии разными гранями облика, характера, речи, еще предстоит выяснить биографам Муравьева, и эта задача совсем не проста. Муравьев практически не вел дневника в общепринятом смысле этого слова. В течение нескольких лет - в 1920-1926 гг. - он писал лишь философский дневник, который начал в бывшем имении Онег, куда уехал после изматывающих месяцев ареста и следствия по делу 
Всероссийского Национального центра, когда его самого и его собратьев то мучили допросами, то приговаривали к высшей мере, тут же заменяя ее тюремным заключением, и наконец освободили по амнистии. Личных записей в этом дневнике нет: Муравьев прорабатывает в нем темы статей и крупных работ, предпочитая мыслить о всеобщем, а не единичном, о человечестве, а не о своей собственной частной судьбе. И лишь несколько разрозненных ранних записей, относящихся ко второй половине 1910-х гг., приоткрывают завесу над тайной душевной жизни философа, для которого софийная тема была глубоко личной, собственной темой.

Да, присутствовавшее у Муравьева на первом этапе работы над мистерией стремление вести рассказ о Софии от первого лица вовсе не было данью интеллектуальной игре. Мыслитель стремился претворить в художественно-философском тексте свой собственный внутренний путь. Сохранившиеся в архиве мыслителя листки записной книжки 1915 г. указывают на то, что любовь к «женщине, именуемой Софиею...», о которой говорит в черновых набросках к мистерии его герой, была частью жизни самого автора. В дневниковых записях Муравьев называет любимую женщину то «С. Д.», то «моя дорогая Sophy». Он пишет ей взволнованное письмо, и оно раскрывает в молодом мыслителе того самого «искателя царства», каким в первых версиях мистерии станет у него Егорий: «Мне грустно, что я не принес Вам какую-нибудь победу, какое-нибудь свое “взятие Перемышля". Везде всходы, всходы, всходы и жатвы никакой. Я знаю, Вы не ищете жатвы и удивляетесь моему вечному устремлению. Но я верю, что найду, и чем яснее я вижу, что я не нашел, - тем яснее я вижу, что найду» ${ }^{31}$. А в набросках к мистерии, датированных 4 и 7 апреля 1921 г., герой, исполненный духовной жажды, рассказывает историю своих исканий Бога и своей любви к Софии. Для нее он готов добыть истинное царство, то, о котором она мечтает: царство небесное и одновременно земное, исполненное радости преображения, неисчерпаемой вечной жизни ${ }^{32}$.

Внимание Муравьева к теме софийности диктовалось той установкой на универсальность, которая была свойственна его мыслительному и духовному складу. Дипломат, один из 
участников Гаагской конференции мира, философ, воспринявший от Ф. М. Достоевского, Н. Ф. Федорова, В. С. Соловьева принцип всечеловечности, пафос всеобщего дела, идеал религиозного единства, он напряженно искал то основание, на котором мог бы воздвигнуться целостный религиознообщественный строй. Актуальность этого поиска со всей очевидностью обозначилась в годы Первой мировой войны, революции, гражданской войны, когда не только земляне, но и граждане одной страны перестали сознавать себя единым телом, согласившись с тем, что ткань человечества и ткань народа разорвана пополам, как разорвано в роде людском и пространство веры, разделенное религиозными, конфессиональными, догматическими, обрядовыми перегородками. Сшить воедино эту ткань Муравьев предлагает, опираясь на принцип софийности, позволяющий видеть и оценивать природу, человека, Вселенную не только в их наличном состоянии - противоречивом, смертном, разрозненном, - но и в перспективе преображения, в свете их идеальной природы, с точки зрения того, чем они призваны стать. Муравьев видит в софийности соединение образа веры и принципа действия, идеалотворчества и стремления к воплощению идеала. Уже в первой сцене мистерии его герой Китоврас, представляя Софии разные трактовки ее образа в традиции русской религиозной мысли, подчеркивает, что этот образ «все более и более отодвигает на задний план другие догматы и религиозные обряды», постепенно отождествляясь со всем, что раньше почиталось и утверждалось Церковью, и особенно Церковью православной: «Она - Субстанция Св. Троицы, она первозданное естество тварей, великий корень целокупной твари, она - ангел Хранитель мира, она - идеальная Личность мира, она - Память Божия, Она - Источник Любви, бытия и истины. Она - Церковь, она - Царство. Она - Дом Божий, Великий Город, Иерусалим Небесный. Она отождествляется с Богоматерью, со Святым Духом, с Троицей, с Христом, с самим Богом» ${ }^{33}$. Китоврас призывает к смелому и свободному шагу: «...раз София является и в Ветхом Завете, и в Христианском богословии, и в мистике, и в религиозной философии всеобъемлющим началом, первенствующим и обосновывающим 
все остальные, - бытие ее и деятельность следует провозгласить единственными догматами религии и подчинить им все остальные, а может, и вовсе их отменить» ${ }^{34}$. Герой, когда-то помогавший Соломону в строительстве Иерусалимского храма, выступает за рождение обновленной, активно-творческой веры, к созданию синтетической строительной идеологии, способной объединить человечество, говорит о новом мессианстве, охватывающем мир, природу, культуру, и во главе его ставит Софию. А в шестой сцене мистерии, рисующей царство социализма, где большевики-«кинокефалы» с их безрелигиозной соборностью противостоят носителям пассивной христианской веры, ограничившей задачу христианства в мире только спасением души, он демонстрирует универсальность софийной идеи самим поворотом сюжета, где Китоврас, предстающий в данной сцене мистерии в виде «демона-большевика», молит Софию от лица «подземных людей»: «София, дай нам другой фундамент! Сделай так, чтобы не было зла, чтобы не было природы человеческой, чтобы волки зажили мирно с овцами в одном стаде!» ${ }^{35}$, чтобы Храм Будущего больше не строился на крови и главным орудием его строительства стала любовь.

Рассматривая софийность как универсальную категорию, которая может быть объединяющим принципом мысли и действия для людей, стоящих по разные стороны баррикад, Муравьев обращался к теме софийности и после того, как работа над мистерией уступила место другому, более прагматическому и проходному для пореволюционной эпохи проекту - книге «Овладение временем как основная задача организации труда» (М., 1924), после издания которой философ был приглашен на работу в Центральный институт труда. И хотя произносить слово «софийность» в работе, предназначенной для печати в советской России, философ по понятным причинам не мог, отсвет идеи софийности лежит и на «Овладении временем», отчетливо проявляясь в размышлениях философа об искусстве, призванном явить совершенный образ реальности, создать вдохновляющий проект грядущего пересоздания мира, который затем будет воплощен трудовым усилием человечества. В трактате «Культура будущего» (1925-1926) концепту софийности как 
энтелехии мироздания, внутреннему стремлению мира к гармонии и совершенству соответствует понятие эктропии, «движения восходящего», собирающего бытие, противостоящего «всякому нисходящему процессу» в природе ${ }^{36}$. А в набросках работы «Философия действия» о софийности напоминает введенное Муравьевым понятие «центрального сознания-ипостаси», организующего вокруг себя другие ипостаси-сознания, подчиняющего их своему ритму и вовлекающего в целостное, общее действие ${ }^{37}$.

Образ Софии как персонификации Души мира, проявления Вечной Женственности появляется и в художественных текстах Муравьева второй половины 1920-х гг. Правда, героини, соотносящиеся с ее образом, уже не носят имя София, но во всем их облике и поведении проступают ее черты. Такова Василиса Прекрасная, героиня сказки «Полоненное царство». В форме сказочного повествования, раздвигающего границы возможного, Муравьев стремился представить идею творческого преображения мира, создать своего рода художественную параллель к работе «Культура будущего» с ее проектами преобразования общества, преобразования человека, преобразования космоса, воплотить в иносказательной форме федоровский идеал победы над смертью, «творческого обновления природы», «преображения мира» ${ }^{38}$. В сюжете сказки воскрешались многие сюжетные линии мистерии «София и Китоврас». В первоначальных набросках и планах к мистерии Егорий освобождал Софию от ига ненавистного царя Полкана, царство которого воплощало и дробный идеал большевизма, и бытие, страждущее под тяжестью смертных законов. В сказке Егорию соответствует образ Ивана, избавляющего Василису Прекрасную от плена «Чудища злого, змея многоголового» ${ }^{39}$, от Вихоря, что насылает «мучения, болезни» ${ }^{40}$ и смерть. Как и в мистерии «София и Китоврас», здесь присутствует момент Преображения, когда сходит «грубая кора вещества», снимается личина, скрывающая истинный лик. Если в финальной сцене мистерии молодая искательница Сoфия раскрывается как Премудрость Божия, а Пресвитер Иоанн - как Параклет, то Василиса сказки «Полоненное 
Царство» раскрывается как София, а Иван - как Пресвитер Иоанн ${ }^{41}$.

Оживает образ Софии и в последнем по времени идеальном женском образе Муравьева - образе Запавы Путятишны из утопического романа «Остров Буян». Муравьев работал над этим романом в 1927-1928 гг., надеясь продвинуть его в печать. Сделал несколько редакций, стараясь превратить текст в «проходной» и безобидный для идеологического ока цензуры. Однако цензура эту вещь так и не пропустила.

Как и мистерия «София и Китоврас», роман «Остров Буян» был посвящен теме исканий идеального строя жизни, но если в мистерии тема была подана в религиозно-философском ключе, с опорой на федоровско-соловьевскую традицию активного христианства, то в романе «Остров Буян» она представала в фольклорных образах, излагалась языком сказаний и былин, народных преданий, рядилась в одежды солнечного язычества, воспевающего жизнь и радостную силу ее. Основная сюжетная линия осталась прежней, варьировалось лишь ее оформление. Вместо «бенсалемцев», искателей и строителей идеального царства, в романе «Остров Буян» выступали богатыри Могут, Богомил и Будимир, а роль Софии, посылавшей их на поиски совершенного царства, исполняла Запава (или, по первоначальной версии, - Предислава). Вместо Царства Пресвитера Иоанна выступала «Солнцева страна», что раскинулась на острове Буян посреди «моря Окияна»: «там вечное лето, туда улетают на зиму птицы и удаляются гадюки, оттуда прилетают журавли, оттуда приносятся на землю все семена» ${ }^{42}$. Об этой стране рассказала Запаве бабка-ворожея Дубиса, поведав и о том, что на острове Буян «есть бел горюч камень Алатырь, никем не ведомый, под камнем тем сокрыта сила могуча и силе той нет конца» ${ }^{43}$. И вот юная Запава, видящая в сне-видении себя царицей Солнцевой страны, к которой с любовью ластятся звери и птицы, дает клятву: «Не нужно мне ни монист, ни паволок, ни серег, ни камней самоцветов. <...> Я выйду за витязя, который найдет остров Буян, победит огненного змея, достанет мне бел горюч камень Алатырь» $»^{44}$. 
Как и в мистерии «София и Китоврас», где София последовательно оказывалась в царствах, которые строили ее собратья-искатели, Запава Путятишна попадала в каждое царство, созданное богатырями, жаждущими ее руки: царство Могута (царство силы и власти, основанное на идее восточного деспотизма), царство Богомила (жреческая языческая теократия с ее культом рождающей и умерщвляющей силы природы), царство Будимира (фантазия в духе бэконовского Бенсалема: царство, построенное на опытах познания и управления природой, но не солидарными усилиями всех людей, как то виделось Н. Ф. Федорову, а лишь горсткой избранных, превращающих остальных в «армию получеловеков», людей-скотов). Но ни одно из этих царств не кажется ей совершенным. Запава отказывается от гармонии, построенной ценой жизни и счастья тысяч безгласных рабов, - так в мистерии Муравьева протестует сердце Софии против социалистического рая на земле, созданного на крови.

Финал романа «Остров Буян» является прямой аллюзией к той главе мистерии, где София, оказавшаяся в безводной пустыне, слышит мольбу всей природы и призывает всю тварь земли к строительству дороги в грядущий град. Эту ключевую, кульминационную сцену «Софии и Китовраса» Муравьев фактически переносит в роман «Остров Буян». По ходу действия Запава оказывается не в пустыне, образ которой слишком насыщен религиозными аллюзиями, а в глубоком лесу. Пророческий сон героини раскрывает ее как «Солнцеву дочь», управительницу Солнцевой страны, а сама Запава начинает ощущать «свою изначальную связь со всем миром. Она чувствует, что расширяется беспредельно, что растет и вверх и вниз и вширь и вглубь. Она охватывает мир во всех направлениях, отождествляясь со всем в нем находящимся и живущим» ${ }^{45}$. И в этот момент ее, как и Софию философского диалога, окружают странники, среди которых она различает и трех искателей ее руки: Будимира, Богомила, Могута. Подобно героям «Софии и Китовраса», они разочаровались в ранее защищаемых ими идеалах, сознали их дробность и готовы теперь «вместе с всеми людьми искать преображенного царства» ${ }^{46}$. А вслед за ними движутся навстречу Запаве «все народы земли, все племена 
и царства, носители и созидатели телесных и духовных богатств, великие скопища, где рождается и цветет жизнь человеческих поколений» ${ }^{47}$. Все они ищут "царства правды», стремятся войти в «великий и последний город, где будет строиться преображенный мир». И Запава, за которой отчетливо встает образ Софии, становится водительницей человечества в его восхождении к совершенству. Воля и энергия героини, к которой взывают хоры людей: «Веди нас, Запава», опираются на силу всех, «неудержимую, бьющую из глубины <...> существа, силу, умноженную <...> соборным движением» ${ }^{48}$. И не только люди, но все стихии, вся природа, животные, растения, камни, облака, солнце, ветер и др. включаются в общую работу спасения, засыпая, как в завершающей сцене мистерии, бездонную пропасть: колоссальная энергия живой материи направляется не на разрушение и смерть, а на созидание пути к чаемому граду - символу преображенной земли и мира.

Сцена «Софии и Китовраса», перенесенная в «Остров Буян», стала ключом к роману. И хотя Муравьев, следуя устоявшейся жанровой традиции, дал своему произведению определение «утопический», сам он мыслил «Остров Буян» не как утопию, а как проект, как манифестацию целостного идеала, преодолевающего ущербность наличных идеалов истории. Именно поэтому, несмотря на все цензурные тернии, так стремился сохранить в тексте романа финальную сцену моления Софии и общего, соборного труда людей и природы. И лишь в последней редакции, рассчитанной на прохождение сквозь угольное ушко советской цензуры, был вынужден снять эту сцену.

Параллельно разработке софийной темы, возводившей бытие к благобытию, а женское - к его софийному первообразу, Муравьев рассматривал и другой - апостасийный вектор движения: не вперед вверх, а вперед вниз. Как мир и человечество, обладающие свободой выбора, могут идти за Христом, руководствуясь его заповедью «больше сих сотворит» (Ин. 14:12), а могут повернуться к Нему спиной, отдавшись языческому carpe diem, так и женское естество может преображаться и просветляться, пестуя в себе софийное начало, 
а может являть образ, исполненный темной, вампирической силы, как это происходит в малой прозе Муравьева, в его «Неприятных рассказах», написанных в духе Эдгара По. Такова Радована из рассказа «Вампир»: высокая женщина «в лиловом платье с горделивой осанкой», «огненными глазами и чувственным хищным ртом» влюбляет в себя мужчин, доводя их до исступления, идиотизма, самоубийства ${ }^{49}$. Более того, одна и та же женщина может просветлять в себе Софию или, как в платоновском мифе, Афродиту Уранию, а может отдаваться во власть Софии Ахамот, Афродиты Пандемос, и столкновение этих двух Афродит всегда чревато взрывом и катастрофой. Вот барышня Татьяна Порошина из безымянного рассказа, симпатичная, образованная, известная строгостью нравов, желая испытать новые ощущения, заставляет обнажиться своего собеседника во время философского разговора ${ }^{50}$. Вот Лилечка из рассказа «Арканщики», сюжет которого относится к голоду 1920-1921 гг. Ее жених, инженер Александр Николаевич, отправляющийся из хлебной Сибири в голодное Поволжье спасать свою невесту, представляет ее в памяти и воображении как «эфирное», «нежное существо», а придя в дом Лилиной тетки, застает Лиличку за разделкой тела молодой девушки: она соскабливает внутренности в лохань, руки людоедки по локоть в крови, а в кухонных чанах кипит человеческое мясо ${ }^{51}$.

Равным образом и мужчина, в представлении Муравьева, может идти по пути Егория, завоевывающего для Софии все царства мира, спасающего ее от тлена и смерти, а может - по пути Петра из рассказа «Щекотун», доводящего извращенными ласками жену Нину до смерти, а затем пытающегося совершить то же самое с ее сестрой. Вместо служения вечной женственности, избавления ее из смертного плена следует надругательство, мучительство и убийство. «Ты будешь моей куколкой - кричит исступленно герой. - Я щекотун, щекотун, щекотун» ${ }^{52}$.

Соединение в человеке непросветленного, страстно-животного начала, неразрывно сопряженного с жестокостью, злым сладострастием, и идеального образа себя и мира, зова высшей природы Муравьев считал главным парадоксом человеческого 
естества, придавая ему и социальное измерение. Контраст Лилит и Софии, как и контраст Егория и Петра, философ осмыслял как характерную черту склада личности дореволюционной эпохи, ставшей временем заката послепетровской культуры с характерным для нее разрушением цельности древнерусского миросозерцания. Неоднократно подчеркивал Муравьев, что разрушение цельного взгляда на мир, соединяющего гносеологию с этикой, неизбежно приводит к внутреннему дисбалансу, к тому, что вылезает эгоистическая изнанка «я», в отсутствие идеала не знающая никакого удержу. Философ настойчиво стремился преодолеть разрушение цельности человека - то прибегая к художественному слову, как в мистерии «София и Китоврас» и романе «Остров Буян», то методом «от противного», как в «Неприятных рассказах», то прямым философским высказыванием, являя в своих текстах волю к творчеству и осуществлению идеала.

Сплетение софийного и площадного подчас возникало и в личной судьбе Муравьева, в его персональном опыте любви, взаимоотношений с Вечно женственным, обуздания собственной чувственности. В архиве философа - множество женских писем, демонстрирующих палитру отношений между адресатом и отправителем: от высокой дружбы, общения ученика и ученицы à la Чаадаев, который предназначал свои «Философические письма» для некоей дамы, стяжав у современников острое прозвище «дамский философ», до необузданной, подчас болезненной страстности. Одно из писем дышет обидой и оскорбленностью: корреспондентка Муравьева упрекает его в неделикатности и фамильярности, проявленной на вечере у Габричевских, прямо указывая на поразивший ее контраст высокого строя души философа и его бытового поведения ${ }^{53}$. Позднее, соединяя литературу и жизнь, Муравьев введет это письмо-обвинение в первую версию драмы «Советник смерти» (1926-1928). Молодая женщина Елена Монкевич пишет своему учителю и возлюбленному, профессору Рудному, вдохновенные лекции которого она так любила, о «минутах тяжелой реакции», переживаемых ею после их чувственных встреч, после «античных» вечеров на одной интеллигентской квартире, участники которых тщатся 
воскресить «оргиазм» древних греков, на деле же впадают в безобразный и пошлый разврат ${ }^{54}$.

Елена, в имени которой соединяется память о Елене Прекрасной античного мифа и Елене Премудрой русской сказки, выступает у Муравьева еще одной ипостасью Софии. Чуткая сердцем, она хочет спасти Рудного от обессиливающего пессимизма, от неверия в возможность победы добра над злом, в то, что мир может быть гармонизирован и просветлен. Убежденный, подобно своим кумирам, античным философам, в «безнадежности жизни» ${ }^{55}$, Рудный видит единственное утешение в наслаждении, тогда как Елена, жаждущая целостной правды, отказывается принять эту редукцию любви к голой чувственности. Художница, она соединяет идею творчества в красоте с идеей любви как преображающей, исцеляющей силы. Бросившись за Рудным в Сухум, где новый Гегезий задумал совершить самоубийство, Елена кричит ему, уже доставшему револьвер: «Я не позволю вам умереть. <...> Я внесу смысл в вашу жизнь. <..> Я дам вам красоту, я объявлю войну страданию, уродству, смерти» ${ }^{56}$.

По сюжету драмы «Советник смерти» в этой войне Елена проигрывает - Рудный кончает с собой. В финале же пьесы реализуется ключевой для софиологии Муравьева мотив спасения самой Софии. Одинокая, потерянная, с тоской и болью в душе, в одну из весенних ночей Елена оказывается у храма Христа Спасителя. Именно там, по одной из версий мистерии «София и Китоврас», ее героиня впервые встретилась с будущим своим спутником, сошедшим со страниц древнерусских апокрифов, дабы открыть ей правду о ее предназначении. Однако Елена встречает в сквере у храма поначалу только тех персонажей, которые, подобно Рудному, знают и ценят сугубо плотскую, ни к чему не обязывающую любовь: они зовут Сoфию разделить с ними вечер и обещают научить ее «холодно наслаждаться» ${ }^{57}$. И лишь после того, как сама героиня, дойдя до последней грани отчаяния, пытается покончить с собой, бросившись в Москву-реку, появляется ее «Егорий» — молодой художник Миша Миронов, работающий над картиной «Преображение мира» и горячо убежденный в том, что «искусство должно дать миру новый образ» ${ }^{58}$, соединить всех людей 
в общем деле миростроительства. Раньше Елена давала Мише первые уроки живописи, и вот теперь он, возмужавший, устремленный в будущее, вдохновленный своим творческим замыслом, протягивает ей руку помощи, выводя из бездны покинутости и одиночества, зовя «присоединить свою жизнь к общей жизни», включиться в работу совершенствования «людей», «вещей», «всей природы» ${ }^{59}$. Подобно Егорию в первоначальных набросках «Софии и Китовраса», Миша влюблен в Елену Монкевич, и Муравьев прямо подчеркивает, что его любовь целостна, софийна, а значит спасающа, недаром возникает в речах героя характерный для софийной темы у Муравьева образ космического расширения личности, преодолевающей свою обособленность от других «я» и от мира: «Когда я думаю о Вас, я расширяюсь, передо мной открывается мир, жизнь моя раздвигается и освещается» ${ }^{60}$.

Борьба в мужчине образов Егория и Петра, в женщине образов Лилит и Софии отчетливо проступает в истории переписки Муравьева с молодой женщиной Евгенией Николаевной. В своем первом письме - от 18 мая 1926 г. - она дерзко и почти цинично предлагает себя, и ее эпатаж вызывает ответное письмо Муравьева, в котором он бережно и почтительно увещевает свою корреспондентку, раскрывая перед ней целостный образ любви, ориентируя не на разврат, а на этику преображенного эроса. Письмо философа, призванное просветить, исцелить и спасти, наполнено аллюзиями к тексту мистерии «София и Китоврас». Муравьев ставит перед своей корреспонденткой образ Софии, которая в одной из сцен мистерии предстает в обличье решительной и бесстрашной царицы амазонок: «Вы вся - вопрос, и все Ваши поступки вопрос, крик внутренней неудовлетворенности... А ответ? Есть ли он в результате сегодняшнего опыта. Нет, конечно, но частица его есть и частица эта говорит определенно: это все можно, это все неважно, но не в этом все-таки то, что Вы ищете... Это тупик, пряный и одуряющий, иногда дающий удовольствие - но никогда не выводящий к счастью. Счастье - шире, счастье - больше, счастье - светлее. Оно имеет иную - поднебесную, великую природу, оно зовет не этими маленькими шепотами, но огромными, безудержными 
голосами. Сядьте на коня, могучая царица амазонок, подобно Таместрис древних времен, ищите славу Александра. Вы смелы и сильны - Вы завоевательница! Идите дорогой расширения, а не узкими путями - которые кажутся Вам мужскими, а на самом деле, они всецело женские. Ибо у них нет истинного горизонта...» ${ }^{61}$.

Получив ответ Муравьева, его корреспондентка пишет второе письмо. От первого - резкого, цинично-безыдеального - его отделяют всего две недели. Но тон текста, отосланного адресату 1 июня 1926 г., совершенно иной. В письме нет и тени пошлости, вызова, эпатажа. Все лучшее, все сокровенное в женской душе, расцветает и преображается, озаренное вдохновляющим словом того, в ком еще недавно она хотела видеть только случайного проводника в мир наслаждений. Корреспондентка Муравьева обращается к нему как к другу, помощнику и спасителю, припадая к мыслителю, почти как София к Егорию: «Я не знала, каким нежным и хорошим можете Вы быть. Вы обрадовали меня теплыми словами, пригревшими и давшими мне надежду на возможность выйти из тупика и стать на лучший путь. У Вас есть желание помочь мне возродить душу, направив мысли в иное русло. Если бы только удалось это, как должна буду я тогда Вас благодарить. Все, что окажется лучшим во мне, что и не родилось еще, а только может быть намечается где-то в тайниках, все, все отдам Вам, дорогой друг» ${ }^{62}$.

Софийная тема, пронизавшая наследие Муравьева, соединила линии его мысли и жизни, художественного творчества и личной судьбы. Он вошел в ряды русских религиозных философов как рыцарь «Неведомой России», «еще не жившей, еще не рожденной» ${ }^{63}$, но долженствующей воплотиться в реальность, и как рыцарь Софии, художницы мироздания, ведущей его к бессмертию и совершенству. 


\section{Примечания}

* Исследование выполнено при поддержке Российского научного фонда (проект № 17-18-01432) в Институте мировой литературы им. А. М. Горького РАН.

1 ОР РГБ. Ф. 189. К. 17. Ед. хр. 2. Л. 39.

2 Текст мистерии и материалы первых редакций, историю текста и комментарий см.: Муравьев В. Н. Сочинения: в 2 кн. М., 2011. Кн. 1. С. 55-474, 595-696.

3 Соловьев В. С. Смысл любви // Соловьев В. С. Сочинения: в 2 т. М., 1990. T. 2. C. 540.

4 Булгаков С. Н. Философия хозяйства // Булгаков С. Н. Сочинения: в 2 т. М., 1993. Т. 1. С. 158.

5 Флоренский П. А. Столп и утверждение Истины // Флоренский П. А. Сочинения: в 2 т. М., 1990. Т. 1 (1). С. 391.

6 Там же. С. 375.

7 Соловьев В. С. Россия и Вселенская Церковь. М., 1911.

8 Это версия впервые была представлена в храме Николы Надеина в стенописи на заднем своде, в Духовской церкви и церкви Иоанна Предтечи в Ярославле [Брюсова].

9 Флоренский П. А. Столп и утверждение Истины. С. 381.

10 Муравьев В. Н. София и Китоврас // Муравьев В. Н. Сочинения. Кн. 1. C. 60 .

11 Там же.

12 Там же. С. 73.

13 Сказание об Индийском царстве // Летописи русской литературы и древности. СПб., 1859. Т. ІІ. Кн. 4. С. 100.

14 ОР РГБ. Ф. 189. К. 17. Ед. хр. 13. Л. 84 об.; Ед. хр. 8. Л. 5.

15 Там же. Ед. хр. 1. Л. 11 об.

16 Муравьев В. Н. Избранные планы мистерии // Муравьев В. Н. Сочинения. Кн. 1. С. 397.

17 Муравьев В. Н. Русский революционный мессианизм // Русская свобода. 1917. № 1. С. 17.

18 Достоевский Ф. М. Полн. собр. соч.: в 30 т. Л.: Наука, 1975. Т. 14. С. 289.

19 Муравьев В. Н. Русский революционный мессианизм. С. 17.

20 ОР РГБ. Ф. 189. К. 17. Ед. хр. 2. Л. 39.

21 Достоевский Ф. М. Материалы к роману «Бесы» // Достоевский Ф. М. Полн. собр. соч. СПб., 1906. Т. 8: Бесы. С. 607. В уточненной расшифровке Б. Н. Тихомирова, не меняющей смысла текста: «земная природа духа человеческого» [Тихомиров: 234].

Муравьев В. Н. София и Китоврас. С. 362.

23 Там же. С. 363.

24 Такое понимание идеала обосновал друг и единомышленник Муравьева философ Н. А. Сетницкий в книге «О конечном идеале» (Харбин, 1932). Доказывая, что момент воплощения является ключевым моментом становления идеала, Сетницкий подчеркивал, что степень воплотимости 
идеала напрямую зависит от степени его цельности, от его близости к совершенству, к тому единому и единственному «целостному идеалу», которого ищет человечество на протяжении своей истории. Хотя работа Сетницкого увидела свет в журнальной версии лишь в 1929 г., а полностью была напечатана в 1932 г., первый и интенсивный этап работы над ней относился к первой половине 1920-х гг., и многие из идей будущей книги Сетницкий обсуждал с В. Н. Муравьевым и другим участником идейного триумвирата А. К. Горским. Муравьев В. Н. София и Китоврас. С. 342.

26 Там же. С. 346.

27 Там же. С. 348.

28 Там же. С. 357.

29 Там же. С. 394.

30 Там же.

31 ОР РГБ. Ф. 189. К. 21. Ед. хр. 2. Л. 6, 26 а.

32 Там же. К. 17. Ед. хр. 13. Л. 42-43.

33 Муравьев В. Н. София и Китоврас. С. 98.

34 Там же.

35 Там же. С. 340.

36 Муравьев В. Н. Культура будущего // Муравьев В. Н. Сочинения. М.: ИМЛИ РАН, 2011. Кн. 2. С. 216.

37 Муравьев В. Н. Материалы к работе «Философия действия»// Там же. С. 310 .

38 Муравьев В. Н. Полоненное царство // Там же. С. 514, 513.

39 Там же. С. 515.

40 Там же. С. 514.

41 См.: Там же. С. 513.

42 Муравьев В. Н. Остров Буян // ОР РГБ. Ф. 189. К. 1. Ед. хр. 2. Л. 31-32.

43 Там же. Л. 31.

44 Там же. Л. 42.

45 Там же. Л. 364.

46 Там же. Л. 364.

47 Там же.

48 Там же. Л. 365.

49 ОР РГБ. Ф. 189. К. 8. Ед. хр. 5.

50 Там же. Ед. хр. 35.

51 Там же. Ед. хр. 4.

52 Там же. Ед. хр. 24.

53 Там же. К. 22. Ед. хр. 18.

54 Там же. К. 7. Ед. хр. 10.

55 Муравьев В. Н. Советник смерти // Муравьев В. Н. Сочинения. Кн. 2. C. 441 .

56 Там же. С. 485.

57 Там же. С. 489.

58 Там же. С. 456.

59 Там же. С. 494. 
60 Там же. С. 457.

61 ОР РГБ. Ф. 189. К. 22. Ед. хр. 3. Л. 21.

62 ОР РГБ. Ф. 189. К. 22. Ед. хр. 20. Л. 2.

63 Муравьев В. Н. Неведомая Россия // Муравьев В. Н. Избранные философские и публицистические произведения. М.: РОССПЭН, 1998. С. 25.

\section{Список литературы}

1. Брюсова В. Г. София Премудрость Божия в древнерусской литературе и искусстве. - М.: Белый город. 2006. - 207 с.

2. Гачева А. Г., Казнина О. А., Семенова С. Г. Философский контекст русской литературы 1920-1930-х годов. - М.: ИМЛИ РАН, 2003. - 400 с.

3. Гачева А. Г. Идеи и образы Ф. М. Достоевского в творческом наследии В. Н. Муравьева. Статья первая // Достоевский и мировая культура. Альманах № 29. - СПб., 2012. - С. 250-264.

4. Гачева А. Г. Идеи и образы Достоевского в творческом наследии Валериана Муравьева. Статья вторая // Достоевский и мировая культура. Альманах № 30. - СПб., 2013. - Ч. 2. - С. 212-238.

5. Гачева А. Г. Гностические мотивы в философской мистерии В. Н. Муравьева «София и Китоврас» // Россия и гнозис. Труды международной научной конференции «Раннехристианский гностический текст в русской культуре». - СПб., 2015. - Т. 1. - С. 15-51. (а)

6. Гачева А. Г. От имяславия к имядействию: А. К. Горский, Н. А. Сетницкий, В. Н. Муравьев в кругу споров об имени // Вопросы философии. - 2015. - № 3. - С. 122-136. (b)

7. Захаров В. Н. Христианский реализм в русской литературе (постановка проблемы) // Проблемы исторической поэтики. - Петрозаводск: Издво ПетрГУ, 2001 - Вып. 6. - С. 5-20 [Электронный ресурс]. - URL: http://poetica.pro/journal/article.php?id=2511 (15.03.2019). DOI: 10.15393/ j9.art.2001.2511

8. Захаров В. Н. Фантастические страницы Достоевского // Проблемы исторической поэтики. - Петрозаводск: Изд-во ПетрГУ, 2008. Вып. 8. - С. 385-397 [Электронный ресурс]. — URL: http://poetica.pro/ files/redaktor_pdf/1431424731.pdf(15.03.2019). DOI: 10.15393/j9.art.2008.283

9. Касаткина Т. А. О творящей природе слова. Онтологичность слова в творчестве Ф. М. Достоевского как основа «реализма в высшем смысле». - М.: ИМЛИ РАН, 2004. - 479 с.

10. Козырев А. П. Соловьев и гностики. - М.: Издатель Савин С. А., 2007. $-544 \mathrm{c}$.

11. Памятники старинной русской литературы. Сказания, легенды, повести, сказки, притчи. - СПб., 1862. - Вып. III. - 180 с.

12. Сапронов П. А. Русская софиология и софийность. - СПб.: Церковь и культура, 2006. - 440 с.

13. Степанян К. А. «Сознать и сказать». «Реализм в высшем смысле» как творческий метод Ф. М. Достоевского. - М.: Раритет, 2005. - 507 с. 
14. Тихомиров Б. Н. Заметки на полях Академического полного собрания сочинений Достоевского (уточнения и дополнения) // Достоевский и мировая культура. Альманах № 15. - СПб., 2000. - С. 231-244.

15. Hagemeister M. Imjaslavie - Imjadejstvie. Namensmystik und Namensmagie in Rußland (1900-1930) // Namen: Benennung - Verehrung - Wirkung. Positionen der europäischen Moderne. — Berlin, 2009. - S. 77-98.

Anastasia G. Gacheva

A. M. Gorky Institute of World Literature, The Russian Academy of Sciences (Moscow, Russian Federation)

a-gacheva@yandex.ru

\section{A Sophianic Theme in the Artistic and Philosophical Heritage of Valerian Muravyov: from the Mysteries of "Sophia and the Centaur" to the Novel "The Island of Buyan"}

Acknowledgments. The research was funded by the grant of the Russian Science Foundation (Project № 17-18-01432) in A. M. Gorky Institute of World Lilerature (RAS).

Abstract. The sophianic theme, inherent to the Russian religious and philosophical thought of the late 19th - first third of the 20th century, is for the first time envisaged in the article in its relation to the artistic and philosophical creativity of Valerian Nikolayevich Muravyov (1885-1930). In the philosophical mystery "Sofia and the Centaur" (1921-1925) Muravyov brings together two lines of the sofiological theme - theological and artistic ones. Sophia appears in the pages of the mystery as an ideal image of the world and man, and at the same time her image is associated with the theme of the meaning of love, with the ethics of the transformed Eros. It is shown how the key scene of the mystery, the prayer to Sofia of all nature and all mankind followed by the common goal of transformation of the world, evolves into other artistic plans of Muravyov, and is reflected in the sketches of the fairy tale "The Captive Kingdom" (1925) and in the unpublished novel "The Island Buyan" (1926-1928). In the light of the Sofia plot the drama of the philosopher "Adviser for Death" (1927-1928) is considered. The autobiographical origins of the sophiology of Muravyov are revealed.

Keywords: artistic and philosophical creativity of V. N. Muravyov, sophiology, mystery "Sofia and the Centaur", the novel "The Island Buyan", drama "Adviser for Death", transformation of the world and man, motifs, images, autobiographical character 
About the author: Gacheva Anastasia G. - Doctor of Philology, Leading Researcher, A. M. Gorky Institute of World Literature, The Russian Academy of Sciences (ul. Povarskaya 25a, Moscow, 121069, Russian Federation)

Received: June 1, 2019

Date of publication: October 18, 2019

For citation: Gacheva A. G. A Sophianic Theme in the Artistic and Philosophical Heritage of Valerian Muravyov: from the Mysteries of "Sophia and the Centaur" to the Novel "The Island of Buyan". In: Problemy istoricheskoy poetiki [The Problems of Historical Poetics], 2019, vol. 17, no. 4, pp. 242-272. DOI: 10.15393/ j9.art.2019.6842 (In Russ.)

\section{References}

1. Bryusova V. G. Sofiya Premudrost' Bozhiya v drevnerusskoy literature $i$ iskusstve [Sofia the Wisdom of God in Ancient Russian Literature and Art]. Moscow, Belyy gorod Publ., 2006. 207 p. (In Russ.)

2. Gacheva A. G., Kaznina O. A., Semenova S. G. Filosofskiy kontekst russkoy literatury 1920-1930-kh godov [A Philosophical Context of Russian Literature of the 1920s-1930s]. Moscow, A. M. Gorky Institute of World Literature of the Russian Academy of Sciences Publ., 2003. 400 p. (In Russ.)

3. Gacheva A. G. The Ideas and Images of F. M. Dostoevsky in the Creative Heritage of V. N. Muravyov. Article One. In: Dostoevskiy i mirovaya kul'tura. Al'manakh № 29 [Dostoevsky and World Culture. Almanac No. 29]. St. Petersburg, 2012, pp. 250-264. (In Russ.)

4. Gacheva A. G. The Ideas and Images of F. M. Dostoevsky in the Creative Heritage of Valerian Muravyov. Article Two. In: Dostoevskiy i mirovaya kul'tura. Al'manakh № 30 [Dostoevsky and World Culture. Almanac No. 30]. St. Petersburg, 2013, part 2, pp. 212-238. (In Russ.)

5. Gacheva A. G. Gnostic Motifs in the Philosophical Mystery "Sofia and the Centaur" by V. N. Muravyov. In: Rossiya i gnosis. Trudy mezhdunarodnoy nauchnoy konferentsii "Rannekhristianskiy gnosticheskiy tekst v russkoy kul'ture» [Russia and Gnosis. Proceedings of the International Scientific Conference "Early Christian Gnostic Text in Russian Culture"]. St. Petersburg, 2015, vol. 1, pp. 15-51. (In Russ.) (a)

6. Gacheva A. G. From Imiaslavie to Imiadeystvie: A. K. Gorsky, N. A. Setnitsky, V. N. Muravyov in the Disputes about the Name. In: Voprosy filosofii, 2015, no. 3, pp. 122-136. (In Russ.) (b)

7. Zakharov V. N. Christian Realism in Russian Literature (Problem Statement). In: Problemy istoricheskoy poetiki [The Problems of Historical Poetics]. Petrozavodsk, Petrozavodsk State University Publ., 2001, vol. 6, pp. 5-20. Available at: http://poetica.pro/journal/article.php?id=2511 (accessed on March 15, 2019). DOI: 10.15393/j9.art.2001.2511 (In Russ.)

8. Zakharov V. N. Fantastic Fiction on the Pages of Fedor Dostoevsky's Literary 
Works. In: Problemy istoricheskoy poetiki [The Problems of Historical Poetics]. Petrozavodsk, Petrozavodsk State University Publ., 2008, vol. 8, pp. 385-397. Available at: http://poetica.pro/files/redaktor_pdf/1431424731.pdf (accessed on March 15, 2019). DOI: 10.15393/j9.art.2008.283 (In Russ.)

9. Kasatkina T. A. O tvoryashchey prirode slova. Ontologichnost' slova v tvorchestve F. M. Dostoevskogo kak osnova "realizma v vysshem smysle» [About the Creative Nature of the Word. Word Ontology in the Creative Work of Fedor Dostoevsky as the Basis of "Realism in the Best Sense of the Term"]. Moscow, A. M. Gorky Institute of World Literature of the Russian Academy of Sciences Publ., 2004. 479 p. (In Russ.)

10. Kozyrev A. P. Solovev i gnostiki [Solovyov and Gnostics]. Moscow, Savin S. A. Publ., 2007. 544 p. (In Russ.)

11. Pamyatniki starinnoy russkoy literatury. Skazaniya, legendy, povesti, skazki, pritchi [Texts of Ancient Russian Literature. Stories, Legends, Novels, Tales, Parables]. St. Petersburg, 1862, issue 3. 180 p. (In Russ.)

12. Sapronov P. A. Russkaya sofiologiya i sofiynost' [Russian Sophiology and Sophian Character]. St. Petersburg, Tserkov' i kul'tura Publ., 2006. 440 p. (In Russ.)

13. Stepanyan K. A. «Soznat' i skazat”». «Realizm v vysshem smysle» kak tvorcheskiy metod F. M. Dostoevskogo ["To Realize and to Say". "Realism in the Best Sense of the Term" as an Artistic Method of F. M. Dostoevsky]. Moscow, Raritet Publ., 2005. 507 p. (In Russ.)

14. Tikhomirov B. N. The Notes on the Margins of the Academic Complete Works of Dostoevsky (Clarifications and Additions) In: Dostoevskiy i mirovaya kul'tura. Al'manakh № 15 [Dostoevsky and World Culture. Almanac No. 15]. St. Petersburg, 2000, pp. 231-244. (In Russ.)

15. Hagemeister M. Imjaslavie - Imjadejstvie. Namenmystik und Namensmagie in Rußland (1900-1930) In: Namen: Benennung - Verehrung - Wirkung. Positionen der europäischen Moderne [Name: Name - Worship - And-Effect. Positions of European Modernity]. Berlin, 2009, pp. 77-98. (In German) 